\title{
Adaptive Adjustment in Taraxacum Officinale Wigg. in the Conditions of Overburden Dump
}

\author{
Olga Legoshchina ${ }^{1}$, Irina Egorova ${ }^{1, *}$, and Olga Neverova ${ }^{2}$ \\ ${ }^{1}$ Institute of Human Ecology of the SB RAS, Leningradskiy avenue, 10, Kemerovo, 650065, Russia \\ ${ }^{2}$ Kemerovo State University (KemSU), 73, Sovietskiy pr., Kemerovo, 650000, Russia
}

\begin{abstract}
Morphological and anatomical features of the leaves and roots of Taraxacum officinale Wigg., growing under the conditions of the rocky dump of the Kedrovsky coal mine of the Kemerovo region, were studied. It was revealed that the specific environmental conditions of the dump cause morphological and anatomical changes in the leaves and roots of the dandelion. At the level of morphology, a decrease in the average leaf area, a thickening of leaf blades, a tendency to decrease the number of leaves in the rosette, a significant decrease in the mass and length of the roots. At the level of the anatomical structure of the leaves, there is a significant increase in the thickness of the mesophyll, a tendency to decrease the thickness of the tissues of the upper and lower epidermis, a decrease in the number of cells in $1 \mathrm{~mm}^{2}$ and an increase in the size of stomata in the tissues of the lower and upper epidermis, a decrease in the number of stomata by $1 \mathrm{~mm}^{2}$ and a stomatal index on the upper epidermis. At the level of the anatomical structure of the roots, the radius of the root decreases, the radius of the cortex and phloem, the diameter of the xylem.
\end{abstract}

\section{Introduction}

As a result of coal mining, the area of disturbed land in Kuzbass is more than 100 thousand hectares. As a result of the open method of coal mining, the emerging rock dumps are characterized by specific ecological conditions - a lack of productive moisture, failed water permeability, a contrasting temperature regime on different relief elements; low potential fertility of embriozems, therefore they are a classical object for studying the adaptive mechanisms of plants planted on them. A high degree of resistance of some species of higher plants is provided by a combination of morphological, physiological, anatomical adaptive reactions, which makes these plants potentially capable of improving the quality of the natural environment - urban areas, industrial zones and technogenically disturbed lands. Adaptations of plants are associated, first of all, with the rearrangements of their assimilating organs, which, in connection with their gas exchange function, are highly sensitive to external influences [1]. It is known that morphological and anatomical rearrangements change the physiological status of plants in extreme conditions of existence for more efficient use of environmental resources [2]. The aim of the work is to study adaptive rearrangements at the morphological and anatomical level in Taraxacum officinale Wigg., which grows in conditions of the rocky dump of the Kedrovsky coal mine.

\footnotetext{
*Corresponding author: nir_kem@mail.ru
} 


\section{Materials and Methods}

Studies were carried out on the rock dump "Southern" of the Kedrovsky coal mine.The dump has a flat-inclined relief with a height of $58 \mathrm{~m}$, an area of 599.3 hectares. Dump rocks are represented by sandstone $(60 \%)$, siltstones $(20 \%)$, mudstones $(15 \%)$, loams and clays $(5 \%)$. The experimental site is located at the top of the dump (the location coordinates of

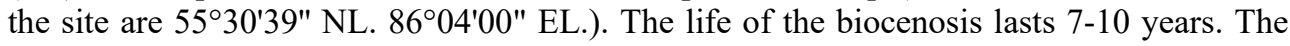
technical and biological stages of recultivation (landings of Pinus sylvestris L. and Onobrychis arenaria (Kit.)), the initial stages of the formation of meadow communities are observed; and there are separate sections of stony scatterings of up to $3 \mathrm{~m}^{2}$ in size from various rock formations completely devoid of vegetation. Projective coverage is up to $50 \%$, on rocky areas - below $10 \%$. There is no turfness. In the herbage prevail Onobrychis arenaria, Taraxacum officinale Wigg, Melilotus officinalis (L.) Pall., Artemisia sericea Web. Ex Stechm., Picris hieracioides L. Embriozems are characterized by an alkaline reaction ( $\mathrm{pH}$ of water extract 7.1-7.7), medium availability of humus (3.5\%), low availability of mobile forms of phosphorus (10-50 mg / kg) and nitrogen (3.6-6.0 mg / kg), high potassium $(100-140 \mathrm{mg} / \mathrm{kg})$, a lack of productive moisture $(19-22 \mathrm{~mm}$ in the $0 \ldots 20 \mathrm{~cm}$ layer).

The control plot was located $15 \mathrm{~km}$ north-west of the dumps at the border of the birch forest. A large area (about $80 \%$ ) of the site is occupied by gramineous herb meadow. Projective coverage is $95-100 \%$, the soil is not turfed. The meadow communities are dominated by Centaurea scabiosa L., Hieracium umbellatum L., Lathyrus pratensis L., Achillea Asiatica Serg., Taraxacum officinale Web.

The object of research was common dandelion (Taraxacum officinale Wigg.), as the most widespread type of perennial herbaceous plants growing on dumps. Preparation of raw materials was carried out in dry sunny weather, according to generally accepted rules during the maximum development of the vegetative mass (end of May 2016). Collected raw materials with no visible signs of damage from 15 sites with a size of $1 \mathrm{~m}^{2}$ from the experimental and control sites. For morphological studies, the sample of plants from each registration site was 10 plants, total from the experimental and control sites -150 plants. The area of the leaves (S) was determined by scanning them and then processing the image using the computer program Image Tools. For anatomic research, plant material was fixed in a $60 \%$ solution of ethyl alcohol. From the middle part of the leaf blade and root, transverse sections were made by a microtome and placed into glycerol. Measurements of the anatomical parameters of the leaves (the thickness of the leaf and its tissues, the number of cells in $1 \mathrm{~mm}^{2}$ of the lower and upper epidermis, stomata sizes) and roots (root radius, cortex, phloem, diameter of the xylem) were carried out with the Axioscope- $2+$ microscope, model ZEISSN HBO103 and N XBO75 (Germany) with eyepiece micrometer, camera and software. Calculation of the stomatal index $(S I)$ was carried out according to the formula:

$$
S I=N_{\mathrm{st}} * 100 \% /\left(N_{\mathrm{st}}+N_{\mathrm{ke}}\right) \text {, }
$$

Where $N_{\mathrm{st}}$ is the number of stomata per $1 \mathrm{~mm}^{2}$, and $N_{\mathrm{ke}}$ is the number of the major epidermal cells of the leaf per $1 \mathrm{~mm}^{2}$. Mathematical processing and interpretation of the experimental results were carried out using the Statistika 8.0 application software package, descriptive statistics.

\section{Results and Discussion}

A comparative analysis of the morphological parameters of a dandelion growing in various ecological conditions has shown that in the waste dumps in plants with a high degree of reliability, the green leaf mass decreases from one plant (by 20\%), the average leaf area (by $39 \%$ ), the mass and length of the root (by 46 and 35\%, respectively), there is a tendency to 
decrease the number of leaves in the rosette, the leaf blade thickens (by 15\%) (Table 1, Figure 1).

Table 1. Morphological characteristics of leaves and roots Taraxacum officinale Wigg.

\begin{tabular}{|c|c|c|c|c|c|c|}
\hline \multirow[t]{2}{*}{ Variants } & \multicolumn{6}{|c|}{ Characteristics } \\
\hline & $\begin{array}{c}\text { Green } \\
\text { weight } \\
\text { from one } \\
\text { plant, gm }\end{array}$ & $\begin{array}{l}\text { Length } \\
\text { root, } \\
\text { cm }\end{array}$ & $\begin{array}{l}\text { Mass of a } \\
\text { root, gm }\end{array}$ & $\begin{array}{l}\text { Average } \\
\text { area of a } \\
\text { leaf, } \mathbf{c m}^{2}\end{array}$ & $\begin{array}{l}\text { Num- } \\
\text { ber of } \\
\text { leaves } \\
\text { rosette, } \\
\text { pcs. }\end{array}$ & $\begin{array}{c}\text { Thickness } \\
\text { of leaf } \\
\text { blade, } \\
\mu \mathrm{m}\end{array}$ \\
\hline $\begin{array}{l}\text { Control: } \\
\text { Leaves - } \\
\text { Roots - }\end{array}$ & $\begin{array}{l}20.52 \pm 1.97 \\
5.58 \pm 0.54\end{array}$ & $12 . \overline{87 \pm 1} .12$ & $5.58 \pm 0.54$ & $\begin{array}{c}40.62 \pm 3.83 \\
-\end{array}$ & $\begin{array}{c}5.80 \pm 0.45 \\
-\end{array}$ & $\begin{array}{c}118.10 \pm 3.22 \\
-\end{array}$ \\
\hline $\begin{array}{l}\frac{\text { Experi- }}{\text { ence: }} \\
\text { Leaves - } \\
\text { Roots - }\end{array}$ & $\begin{array}{r}16.40 \pm 1.32 \\
3.01 \pm 0.25\end{array}$ & $8.38 \pm 0.63$ & $3.01 \pm 0.25$ & $\begin{array}{c}24.74 \pm 1.62 \\
-\end{array}$ & $\begin{array}{c}4.92 \pm 0.42 \\
-\end{array}$ & $\begin{array}{c}136.25 \pm 6.22 \\
-\end{array}$ \\
\hline
\end{tabular}

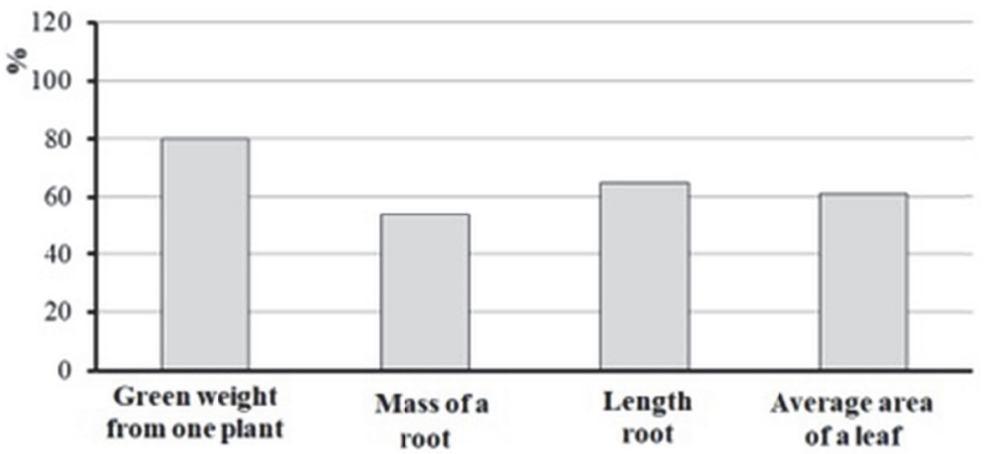

Fig. 1. Changes of morphometric indexes of Taraxacum officinale Web. in the conditions of a dump ( $\%$ of control)

It is known that growth is one of the largest consumers of energy therefore his shutdown expands the power opportunities necessary for adaptive reorganizations. The values of morphometric indexes of leaves and roots of the dandelion growing on pedigree dumps received by us confirm the aforesaid. It is known that at growth in droughty conditions and big insolation grassy plants have an increase in thickness of a plate of a leaf and assimilatory tissue [3]. P. É. Lauri et al. [4] established that the lack of moisture leads to decrease of the area of a leaf blabe and its weight in absolute values that can be considered as adaptive reaction to adverse factors of the environment.

The revealed morphometric changes at a dandelion are manifestation of a kserofitization - the adaptive reaction at the level of the whole plant directed to survival in adverse conditions of a dump. Analysis of the anatomical structure of the leaves showed that under the conditions of the rock dump in the dandelion, the thickness of the mesophyll (by 55\%) increases reliably (Fig. 2), there is a tendency to decrease the thickness of the tissues of the upper and lower epidermis (Table 2); with a high degree of reliability, the anatomical indices of the roots change: in the conditions of a pit heap, the root radius decreases by $21.5 \%$, the radius of the cortex and phloem is reduced by 19.6 and $28.7 \%$, respectively, the diameter of xylem decreases by $30 \%$ (Table. 2, Fig. 3).

Table 2. Anatomo-morphological characteristics of leaves and roots Taraxacum officinale Wigg. 


\begin{tabular}{|l|c|c|}
\hline \multicolumn{1}{|c|}{ Characteristics } & Control & Experience \\
\hline Area of a leaf, $\mathrm{cm} 2$ & $48.02 \pm 4.82$ & $36.43 \pm 3.46$ \\
\hline Number of leaves per plant, pcs. & $5.80 \pm 0.45$ & $4.92 \pm 0.42$ \\
\hline Thickness of a leaf blabe, $\mu \mathrm{m}$ & $1180.10 \pm 3.22$ & $136.25 \pm 6.22$ \\
\hline Tissue thickness, $\mu \mathrm{m}$ & & $18.66 \pm 1.19$ \\
\hline - upper epidermis & $19.61 \pm \mathbf{1 . 2 4}$ & $15.37 \pm 0.42$ \\
\hline - lower epidermis & $16.81 \pm 0,65$ & $103.11 \pm 3.24$ \\
\hline - mesophyll & $84.00 \pm 2.12$ & $4-6$ \\
\hline Number of mesophyll rows, pcs. & $4-6$ & $2310 \pm 18.69$ \\
\hline Radius of root, $\mu \mathrm{m}$ & $2945 \pm 23.14$ & $1743 \pm 12.24$ \\
\hline Radius of cortex, $\mu \mathrm{m}$ & $2170 \pm 35.12$ & $1218 \pm 10.09$ \\
\hline Radius of phloem, $\mu \mathrm{m}$ & $1708 \pm 14.17$ & $1225 \pm 11.24$ \\
\hline Diameter of xylem, $\mu \mathrm{m}$ & $1750 \pm 14.26$ & \\
\hline
\end{tabular}

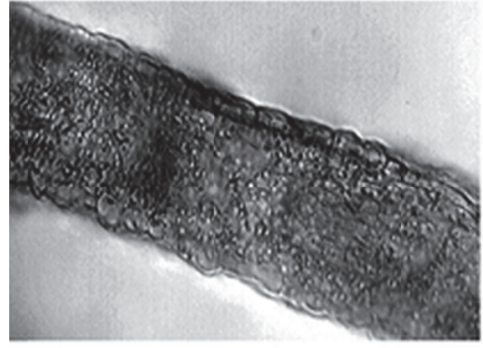

A

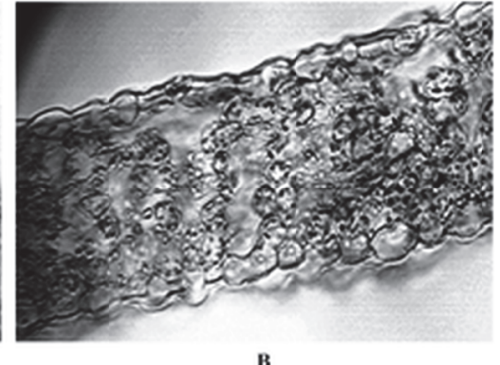

Fig.2. Cross-section of the leaf Taraxacum officinale Wigg. (A - control, B - experience)

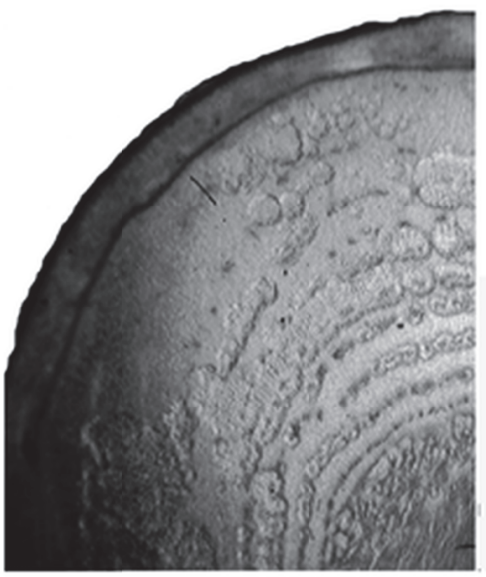

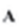

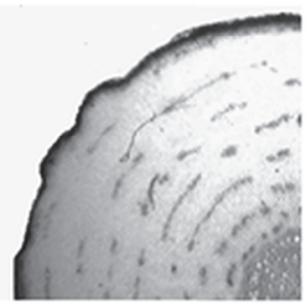

B

Fig. 3. Cross-section of the root of Taraxacum officinale Wigg. (A - control, B - experience)

It is known that adaptation of a plant to adverse conditions of the environment, as a rule, is followed by change of growth rate of roots and bines.

At action of adverse factors of the environment most visually responses of plants are shown in structure of an epidermis of a leaf. The obtained experimental datas confirm differences of anatomic signs of an epidermis of a leaf of a dandelion, growing in the conditions of the rock dump (Table. 3).

Table 3. Anatomical characteristics of the epidermis of the leaf Taraxacum officinale Wigg.

\begin{tabular}{|l|l|l|}
\hline Characteristics & Lower epidermis & Upper epidermis \\
\hline
\end{tabular}




\begin{tabular}{|l|c|c|c|c|}
\hline & Control & Experience & Control & Experience \\
\hline $\begin{array}{l}\text { Number of cells } \\
\text { in } 1 \mathrm{~mm}^{2}\end{array}$ & $978.80 \pm 24.32$ & $924.45 \pm 16.23$ & $\begin{array}{c}1042.37 \pm 25.6 \\
2\end{array}$ & $940.44 \pm 20.08$ \\
\hline $\begin{array}{l}\text { Number of stoma- } \\
\text { ta in } 1 \mathrm{~mm}^{2}\end{array}$ & $142.02 \pm 1.29$ & $125.01 \pm 1.34$ & $81.01 \pm 1.14$ & $60.02 \pm 0.82$ \\
\hline $\begin{array}{l}\text { Length of stoma- } \\
\text { ta, } \mu \mathrm{m}\end{array}$ & $24.36 \pm 0.47$ & $26.12 \pm 0.58$ & $23.65 \pm 0.52$ & $24.28 \pm 0.46$ \\
\hline $\begin{array}{l}\text { Width of stomata, } \\
\mu \mathrm{m}\end{array}$ & $19.32 \pm 0.41$ & $20.54 \pm 0.67$ & $17.93 \pm 0.36$ & $18.44 \pm 0.92$ \\
\hline Stomatal index, $\%$ & $12.67 \pm 0.25$ & $11.87 \pm 0.11$ & $7.21 \pm 0.28$ & $6.21 \pm 0.36$ \\
\hline
\end{tabular}

In particular, in the common dandelion plants growing on dumps, there is a tendency to decrease the number of cells in $1 \mathrm{~mm}^{2}$ and to increase the size of stomata in the tissues of the lower and upper epidermis, the number of stomata is significantly reduced by $1 \mathrm{~mm}^{2}$ (by 12 and 26\%, respectively); on the upper epidermis there is a significant decrease in the stomatal index (by 14\%). Given the low supply of productive embriozems in the waste heaps, a decrease in the stomatal index is a natural reaction of plants aimed at survival.

There is information in the literature that the low frequency of stomata in combination with their large size contributes to a more effective control of water exchange $[5,6]$. The data obtained by us also agree with the results of the studies of I. I. Krokhmal [7] who established that in $C$. sibirica at the level of rosette leaves adaptation to the harsh conditions of growth is achieved by reducing the number of stomata and increasing their size.

The use of correlation analysis showed that the common dandelion growing in conditions of the rock dump increases the number of reliable correlations between the anatomical parameters of the root and the provision of soil with microelements and productive moisture. In particular, in the dandelion, close positive correlations radius of root, radius of cortex and diameter of xylem with phosphorus, nitrogen and productive moisture of embriozems appear in dandelion; the radius of phloem is positively correlated with the nitrogen content and the productive moisture in the soil (Table. 4).

Table 4. Correlation links between anatomical characteristics root Taraxacum officinale Wigg. and agrochemical indicators embryozems

\begin{tabular}{|l|l|l|}
\hline \multirow{2}{*}{ Dependence of the studied features } & \multicolumn{2}{l|}{$\begin{array}{l}\text { Reliable correlations } \\
(\mathrm{r}), \mathrm{n}=150, \mathrm{p}<0.05\end{array}$} \\
\cline { 2 - 3 } & Control & Experience \\
\hline Radius of root - phosphorus content & - & +0.85 \\
\hline Radius of root - nitrogen content & +0.83 & +0.81 \\
\hline Radius of root - productive moisture content & - & +0.87 \\
\hline Radius of cortex - phosphorus content & - & +0.85 \\
\hline Radius of cortex - nitrogen content & +0.80 & +0.81 \\
\hline Radius of cortex - productive moisture content & - & +0.83 \\
\hline Radius of phloem - phosphorus content & +0.81 & - \\
\hline Radius of phloem - nitrogen content & +0.89 & +0.81 \\
\hline Radius of phloem - productive moisture content & - & +0.84 \\
\hline Diameter of xylem - phosphorus content & - & +0.80 \\
\hline Diameter of xylem - nitrogen content & +0.80 & +0.82 \\
\hline Diameter of xylem - productive moisture content & - & +0.85 \\
\hline Total correlations: & $\mathbf{5}$ & $\mathbf{1 1}$ \\
\hline
\end{tabular}

It should be noted that an increase in the total number of correlation links occurs due to the formation of positive correlations, which, as is known, control the development of biosystems and arise in critical periods for the body. The coordinated increase in the number of correlation links between the anatomical characteristics of the common dandelion root and 
agrochemical indices of embryosemes can be considered as a specific reaction aimed at survival and stable existence in conditions of the rock dump.

\section{Conclusion}

Specific ecological conditions of the rock dump (low availability of mobile forms of phosphorus and nitrogen, lack of productive moisture) of the Kedrovsky coal mine cause morphological and anatomical changes in the leaves and roots of Taraxacum officinale Wigg. It has been established that adaptive reactions permitting the survival of Taraxacum officinale Wigg. in conditions of a rock dump are:

- at the level of plant morphology - decrease in leaf mass from one plant, average leaf area, weight and root length, formation of a tendency to decrease the number of leaves in the rosette;

- at the level of the anatomical structure - a significant increase in the thickness of the mesophyll, a tendency to decrease the thickness of the tissues of the upper and lower epidermis, a decrease in the number of cells in $1 \mathrm{~mm}^{2}$ and an increase in the size of stomata in the tissues of the lower and upper epidermis, a decrease in the number of stomata by $1 \mathrm{~mm}^{2}$, epidermis, a decrease in the radius of the root, the radius of the cortex and phloem, the diameter of the xylem. Identified morphological and anatomical changes in Taraxacum officinale Wigg. are a manifestation of xerophytization - an adaptive reaction at the level of the whole plant, aimed at survival in adverse conditions of the heap.

In the conditions of the rock dump, an increase in the number of positive reliable correlations between the anatomical parameters of the root Taraxacum officinale Wigg. and the provision of embryozems with microelements and productive moisture has been established. Positive correlations, as we know, control the development of biosystems and arise in critical periods for the body. The coordinated increase in the number of correlation links between the anatomical characteristics of the dandelion root and agrochemical indicators of embryosemes can be considered as a specific reaction aimed at survival and stable existence in conditions of the rock dump.

\section{References}

1. O.A. Neverova, O.M. Legoshchina, A.A. Bykov, Middle-East J. Sci. Res. 17:3 (2013)

2. M.Yu. Menshakova, V.K. Zhirov, A.Kh. Khaitbaev, R. I. Gainanova, The variability of the photosynthetic apparatus of plants: boreal and subarctic ecosystems (Nauka, Moscow, 2008)

3. L.A. Ivanova, Rus. J. Ecol. 45:2 (2014)

4. P.-É. Lauri, A. Marceron, F. Normand, et al., J. Plant Hydr. 1 (2014)

5. R.Ceulemans, J. Jmpens, R. Lemeur, et al., Oecol. Plant. 13, 1 (1978)

6. D.R Bissing, Amer. J. Bot., 69, 6 (1982)

7. I.I. Krokhmal, Ecol. and Noosph. 26, 1-2 (2015). 